\title{
Legal Formalism
}

\author{
Michael Lobban
}

The era of 'legal formalism' is usually taken to refer to the period in American legal thought between the 1860s and the 1920s, when a new generation of post-bellum treatise writers and legal academics sought to discover the underlying principles of common law cases, and put them into a rational order. This period is sometimes also referred to as the era of 'classical legal thought', a phrase which takes in not only the perceived methodology of the jurists, but a broader Weltanschauung shared by the judiciary, which favoured laissez-faire and individualism. ${ }^{1}$ In contemporary jurisprudence, the term 'formalism' refers to a specific approach to adjudication and constitutional interpretation, which has its defenders as well as its critics. ${ }^{2}$ However, in the era under study, it was neither a term which jurists used to describe themselves, nor one which their critics used to describe them.

'Formalism' was in many ways defined by the antiformalist critiques of the later generation of 'Realist' thinkers. ${ }^{3}$ In the view of the Realists, 'formalists' treated law as a system of abstract concepts, which could be applied by deduction to the facts of any particular case. They were blind to the policy choices and social purposes, which had shaped the content of law. They saw law as an adjudicative system in which judges neutrally resolved disputes between autonomous individuals, rather than one in which legislation played a critical role; and consequently, they privileged private law and marginalised public law. ${ }^{4}$ It generated (in Roscoe Pound's famous critique) a 'mechanical' form of jurisprudence in which rules and doctrines were judged 'by their conformity to a supposed science and not by the results to which they lead. ${ }^{5}$ Recent scholarship has questioned this image of the legal thinkers of the 'Gilded Age'. The range of opinions within 'orthodox' legal thought in this era has been shown to have been rather larger than the Realist caricature suggested, with many jurists developing theories in which moral reasoning and historical investigation played major roles. ${ }^{6}$ As shall be seen in what follows, the 'formalist' jurists were not simply narrow

\footnotetext{
${ }^{1}$ Duncan Kennedy, The Rise and Fall of Classical Legal Thought (2006; $1{ }^{\text {st }}$ written 1975), W.M. Wiecek, The Lost World of Classical Legal Thought: Law and Ideology in America, 1886-1937 (1998), Grant Gilmore, The Ages of American Law (1977), Morton J. Horwitz, The Transformation of American Law, 1870-1960 (1992).
}

${ }^{2}$ See esp. Frederick Schauer, 'Formalism', (1988) 97 Yale LJ 509-548, Frederick Schauer, Playing by the Rules: a Philosophical Examination of Rule-Based Decision-Making in Law and in Life (1991).

${ }^{3}$ See Anthony J. Sebok, Legal Positivism in American Jurisprudence (1998), 49, 57: 'As a theory of law, it exists only as a reflection of scholars like Holmes, Pound, Llewellyn and Frank'.

${ }^{4}$ See Karl Llewellyn's description of the 'Formal Style' in The Common Law Tradition: Deciding Appeals (1960), 38.

${ }^{5}$ Roscoe Pound, 'Mechanical Jurisprudence', (1908) 8 Columbia LR 605 at 606-8.

${ }^{6}$ See Bruce A. Kimball, The Inception of Modern Professional Education: C.C. Langdell, 1 
logicians who had imbibed the learning of analytical jurisprudence. They were scholars bred in the common law tradition, who sought to make sense of it for a new age, by incorporating the methods of the latest jurisprudential learning, both historical and analytical.

\section{I}

If 'formalism' was to be defined by its critics, the locus classicus of that critique is generally agreed to be Oliver Wendell Holmes's 1880 review of Christopher Columbus Langdell's Summary of the Law of Contracts. For Holmes, Langdell was 'the greatest living legal theologian ... so entirely is he interested in the formal connection of things, or logic, as distinguished from the feelings which made the content of logic, and which have actually shaped the substance of the law. ${ }^{7}$ Langdell came to be seen as the intellectual progenitor of an entire 'tradition' of scholars devoted to the taxonomy of legal concepts. He had famously revolutionised law teaching at Harvard by introducing the case method. For Langdell, law, 'considered as a science, consists of certain principles or doctrines', which the student had to master so well as 'to be able to apply them with constant facility and certainty to the evertangled skein of human affairs'. If the volume of case law was massive, fundamental legal doctrines could be teased out of a much smaller number of leading cases. ${ }^{8}$ By a correct classification and arrangement of the material found in the cases, the major categories of law could be identified, the basic principles which underpinned them elaborated, and the rules relating to particular categories put into a rational order.

As Dean of the Harvard Law School, Langdell assembled a group of scholars who applied his method to a range of topics. It included men like James Barr Ames and William A. Keener, who developed his method of case teaching, as well as other colleagues such as John Chipman Gray, Joseph A. Beale and Samuel Williston. Their doctrinal works were replete with comments which suggested a vision of law as a closed system of rational rules. For instance, having figured out the Rule against Perpetuities from case law stretching back to the middle ages, Gray announced that '[i]f the answer to a problem does not square with the multiplication table one may call it wrong, although it be the work of Sir Isaac Newton; and so if a decision conflicts with the Rule against Perpetuities, one may call it wrong, however

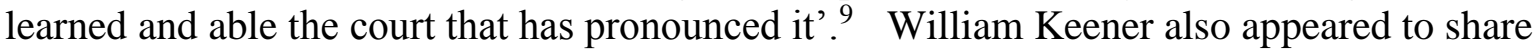
this mechanical vision of science. Explaining the case-method pioneered by Langdell, he stated that ' $[\mathrm{t}]$ he facts of the case correspond to the specimen, and the opinion of the court,

1826-1906 (2009), David Rabban, Law's History: American Legal Thought and the Transatlantic Turn to History (2013), Stephen A. Siegel, 'Francis Wharton's Orthodoxy: God, Historical Jurisprudence, and Classical Legal Thought', (2004) 46 Journal of Legal History 422; Stephen A. Siegel, 'Joel Bishop's Orthodoxy', (1995) 13 Law and History Review 215.

${ }^{7}$ Book Review, (1880) 14 American LR 233-5 at 234.

${ }^{8}$ C.C. Langdell, A Selection of Cases on the Law of Contracts, $2^{\text {nd }}$ ed (1879), ix-x.

${ }^{9}$ J. C. Gray, The Rule against Perpetuities (1886) v. On this work as an example of formalism, see Stephen Siegel, 'John Chipman Gray, Legal Formalism and the Transformation of Perpetuities Law’, (1982) 36 University of Miami LR 439. 
announcing the principles of law to be applied to the facts, correspond to the memoir of the discoverer of a great scientific truth' ${ }^{10}$ For Keener, the misclassification of legal topics was 'not only unscientific, and therefore theoretically wrong' but also 'destructive of clear thinking, and therefore vicious in practice'. ${ }^{11}$ For many Realists, the 'legal fundamentalism' of this kind of scholarship was most clearly encapsulated in Beale's Treatise on the Conflict of Laws. ${ }^{12}$ In this treatise, Beale stated that law was 'not a mere collection of arbitrary rules, but a body of scientific principle'. The general body of law - ius as opposed to lex - was 'a branch of practical philosophy; by which, through the use of reason and experience, legal generalisations may be made'. Purity of doctrine could be lost through wrong decisions, 'thus warping legal principle by bad precedent' and the 'application of general principles may be inhibited by legislation'. Indeed, bad decisions and legislative changes led to the 'peculiar local law of any jurisdiction' deviating from 'the general doctrine of the prevailing legal system'. ${ }^{13}$

Such comments did not however amount to a theory of law. Langdellian 'formalism' did not generate a theory, beyond the occasional statement of method found in prefaces or interleaved in the text. The underlying theory was often inferred by critics, who wished to use it as a foil for their own ideas. Realists who were sceptical about the autonomy of legal doctrine drew their inspiration from Holmes's aphorism - included in his review of Langdell that the 'life of the law has not been logic: it has been experience'. Those who were sceptical about its centrality in determining legal outcomes were inspired by Holmes's later comment that ' $[\mathrm{t}]$ he prophecies of what the courts will do in fact, and nothing more pretentious, are what I mean by the law'. ${ }^{14}$ But in fact, such comments were not out of step with the views expressed by a number of scholars who were tarred with the brush of 'formalism'. Having spent most of his career writing on property law, Gray only turned to jurisprudence in 1909 , when he published The Nature and Sources of the Law. In this work, he argued that law was the set of rules applied by the courts in any state: nothing was law which the judges did not apply as such. ${ }^{15}$ In Gray's opinion, courts were constantly making ex post facto law, and it was entirely open for the court in one common law jurisdiction to decide a novel case differently from a court in the neighbouring jurisdiction. Judges were not investigators uncovering truth, like Newton: if Newton was wrong, the universe remained unmoved; but if

${ }^{10} \mathrm{He}$ added 'the facts of the case correspond to the apple which suggested to Sir Isaac Newton the law of gravitation'. William A. Keener, 'The Inductive Method in Legal Education', (1894) 28 American LR 709 at 713, 718.

${ }^{11}$ William A. Keener, A Treatise on the Law of Quasi-Contracts (1893), 3.

12 Jerome Frank dubbed this approach 'Bealism': Law and the Modern Mind (1949) 55 (1 $1^{\text {st }}$ ed 1930).

${ }^{13}$ Joseph H. Beale, A Treatise on the Conflict of Laws (1916), 135.

${ }^{14}$ O.W. Holmes, 'The Path of the Law', (1897) 10 Harvard LR 457 at 461.

${ }^{15}$ J. C. Gray, The Nature and Sources of the Law (1909), 82. 
judges went awry, their bad decisions remained law. ${ }^{16}$ Even Beale argued for the need to study law with a view to its 'readjustment and reform'. Invoking the new 'sociological jurisprudence' of Pound, he said that 'we must examine the law objectively to learn its social purpose and to see how far that purpose is being accomplished' ${ }^{17}$

In fact, the 'formalist' project of attempting to put the common law into a rational order and to seek underlying principles was one which was engaged in by a large number of scholars on both sides of the Atlantic, who did not think of law as a whole as a closed system of reasoning and would not have seen themselves as Langdellian 'disciples'. They included Holmes himself, as well as such scholars as James Bradley Thayer, John Henry Wigmore and Melville Madison Bigelow in the United States and Frederick Pollock and William Anson in England. The idea that the scholar could seek to put the body of the law into a rational form was not seen as requiring him to adhere to a theory of law which treated it as a closed system. For instance, Bigelow, whose highly 'formalist' Law of Torts commenced with an analytical chapter on 'General Theory and Doctrine', and followed with chapters on specific torts beginning with a 'statement of the duty' involved in each one, told his students that ' $[t]$ he limitations of logic, in the presence of social change - the dangers of it - should be plainly taught'. ${ }^{18}$ In his view, 'a scientific school of law' should study all the 'sources when the law is to be declared' - not only precedents and historical doctrines, but also 'the direct and indirect immediate sub-legal sources - business and pursuit generally, and the other less tangible influences which go up to make the sum total - the political, economic, psychological and personal influences'. ${ }^{19}$ In another lecture, he said 'the law is continuous only in time. In point of substance it is broken up into periods of the ascendancy of certain social and economic forces...the books do not contain, either in development or in germ, all the law'. ${ }^{20}$

\section{II}

When it came to their doctrinal writing, these writers were following in the footsteps of several generations of legal scholars, who had sought to digest and make sense of the increasingly large volume of case law. Ever since the publication of Blackstone's Commentaries, Anglo-American jurists had searched for principles within the common law, and to set them out in logically ordered treatises which commenced with the more general matters and descended to particulars. Nor was the language of scientific inquiry new to Langdell. His Harvard predecessor, Simon Greenleaf, said in 1838 that '[a]djudged cases, are, to the philosophical student of the law, what facts are to the student of natural science.

${ }^{16}$ Gray (n. 15) 97, 99.

${ }^{17}$ Joseph H. Beale, 'The necessity for a study of Legal System', 1914 AALS Proceedings 31, 39. Quoted in Brian Z. Tamanaha, Beyond the Formalist-Realist Divide: the Role of Politics in Judging (2010), 16.

${ }^{18}$ Melville M. Bigelow, Centralization and the Law: Scientific Legal Education (1906), 183.

${ }^{19}$ Bigelow (n. 18) 203.

20 'Notes' (1907) 23 LQR (1907) 1-4 at 2. 
They are the elements from which, by the process of induction, his mind ascends to the higher regions of the science, scans it boldest outlines, and familiarises itself with its great and leading principles. ${ }^{, 21}$ What made the literature of the later nineteenth century appear innovative was its greater rigour than many earlier treatises, which were often digests of cases on fragmented topics, put together by young lawyers seeking to make their name.

There were practical reasons why jurists began to attempt more systematic treatises. With the abolition of the forms of action on both sides of the Atlantic in the third quarter of the nineteenth century, a framework of classification long used by lawyers and law students was removed; and jurists were led to look for substantive principles to make sense of the broader classifications of 'contract' and 'tort'. In this era of reform, it was increasingly evident that a different kind of textbook was needed. In the first treatise on torts, published in Boston in 1859, Francis Hilliard commented that hitherto, this area of the law had always been discussed in books relating to procedure, evidence or the courts. 'By a singular process of inversion', he wrote, 'remedies have been substituted for wrongs'. This was 'to reverse the natural order of things; to give a false view of the law as a system of forms rather than principles; to elevate the positive and conventional above the absolute and permanent'. By rethinking this approach, Hilliard hoped to have 'evolved a series of principles, far less fragmentary and disconnected' than were to be found in the forms of action. ${ }^{22}$ It was this ambition which was shared by the jurists of the Gilded Age.

Three intellectual influences which came together to shape the approach of this new generation of treatise writers. The first was that of common law forensic reasoning. There was a well-established tradition in common law thought that the law was composed of principles and doctrines which had a life outside their expression in particular cases. The common law was conceived of as a body, not as a collection of fragments. This law was not to be found in the verbal formulation of a rule embodied in any particular decision, but in the wider reasoning which explained the case. It was made up of the rationes decidendi, the principles derived from a body of cases. This meant that when a judge had to decide any case, he began with his 'principle for a guide' (as Justice J.T. Coleridge put it), and only then looked to other decisions to see how the principle had been applied in them. ${ }^{23}$ This was a vision which continued to appeal to many jurists. Joel Bishop, who has been described as 'a seminal classical legal scholar' for his methodology, which suggested that broad principles could be induced from case law and then applied deductively to new cases, ${ }^{24}$ saw the law as

21 'Cambridge Law School: Notes of Professor Greenleaf's Introductory Lecture, at the Present Term’ (1838-9) 1 Law Reporter, 217 at 218.

${ }^{22}$ Francis Hilliard, The Law of Torts or Private Wrongs, $2^{\text {nd }}$ ed (1861), vi-vii (1 ${ }^{\text {st }}$ ed 1859).

23 'Copies of the Lord Chancellor's Letters to the Judges, and of their Answers, respecting the Criminal Law Bills of the Last Session', in Parliamentary Papers 1854 (303) LIII 389, p. 12. Quoted in Michael Lobban, 'Legal Theory and Judge-Made Law in England, 1850-1920', (2011) 40 Quaderni Fiorentini 553 at 565.

${ }^{24}$ Siegel, ‘Joel Bishop's Orthodoxy’ (n. 6), at 216, 228. 
system of principles and spoke of particular decisions as being 'evidence of the law'. ${ }^{25} \mathrm{He}$ described a legal system made up of legal 'points' - particular rules which could be identified and enumerated - which could be 'practically reduced to, or merged in, principles', which were 'universal, applying in all cases where its particular nature renders it applicable'. ${ }^{26}$

A similar fidelity to the common law tradition can be seen in the approach both of Holmes and Langdell. In 1870, Holmes explained that 'it is the merit of the common law that it decides the case first and determines the principle afterwards'. Judgments were not made as a matter of logic, with decisions made on the basis of syllogistic deductions from major premises. Rather, the ratio decidendi or principle was worked out later: 'It is only after a series of determinations on the same subject matter, that it becomes necessary to "reconcile the cases", as it is called, that is by a true induction to state the principle which until then has been obscurely felt'. ${ }^{27}$ This was also the approach of Langdell's case-book, which asked students to tease out the wider principle from a collection of cases which were set out in order of their historical development. ${ }^{28}$ They both accepted what was a commonplace by the later nineteenth century: that the common law was a growing and developing system of law, whose flexibility and growth might be stunted by codification.

The second influence was that of Austinian jurisprudence. In his lectures - posthumously published in 1863 - Austin aimed to 'analyse certain notions which meet us at every step, as we travel through the science of law' ${ }^{29}$ and to abstract the "necessary principles, notions and distinctions' to be found in all advanced legal systems. Having defined his legal concepts, Austin sought to map out a system of the different kinds of rights and duties which might exist. Although his definition of law as the command of sovereign came in for much criticism, even his critics saw value in the analytical exercise of defining legal concepts and categories. While Austin also favoured codification, his lectures on jurisprudence served to provide a toolkit for those working in the common law tradition, who did not seek a definitive code. The mass of materials lying in case law would be put into a better and more rational order, if the jurist applied clearer concepts to them. By the second half of the nineteenth century, when the forms of action were being abolished on both sides of the Atlantic, these tools were of increasing importance to jurists seeking a new way of organising law. ${ }^{30}$

${ }^{25}$ Joel Prentiss Bishop, The First Book of the Law (1868) §§ 61, 65-6.

${ }^{26}$ Ibid. $\S \S 185,191$. Principles could be used to overrule erroneous decisions, for 'authority does not consist of cases but of principles' (§ 98).

${ }^{27}$ O. W. Holmes, 'Codes and the Arrangement of Law', (1870) 5 American LR 1.

${ }^{28}$ See Thomas C. Grey, 'Langdell's Orthodoxy,' (1983) 45 University of Pittsburgh LR 1 at $28-32$.

${ }^{29}$ J. Austin, Lectures on Jurisprudence, or the Philosophy of Positive Law (1873) $4^{\text {th }}$ ed (ed. R. Campbell), 34.

${ }^{30}$ The treatise writers who were said to have been the first to put the law into a principled form drew heavily both on Austin's analytical jurisprudence and on the German Pandectist literature which had also inspired him. See for instance S. M. Leake, The Elements of the Law 6 
The third influence was that given by the rival approach of historical jurisprudence. Where Austin's jurisprudence was timeless and static, Sir Henry Maine's Ancient Law (1861) stressed the contingent and changing nature of law. He had argued that in progressive societies, social necessities always ran ahead of law. Three devices - legal fictions, equity and legislation - had been developed in order to ensure that law would keep up. Legal fictions were associated with the common lawyers' predilection for pretending that all remained unchanged, even as they were changing the law. Maine showed that modern conceptions of property and contract were not timeless categories, but had evolved over time, as progressive societies evolved from being based on status to being based on contract. ${ }^{31}$ Maine's work was extremely popular and widely read. His approach to legal questions might have held out the promise of a more sociological jurisprudence, encouraging jurists to relate changes in law to changes in the wider society, and to use law as a vehicle through which to trace and explain changes in social structure. ${ }^{32}$ It might have encouraged jurists to abandon the jurisprudence of concepts and to look for a jurisprudence of purposes, as Jhering's attack on

Begriffsjurisprudenz sought to do. However, Maine did not absolutely reject the Austinian vision: indeed, he endorsed it as the best conceptual apparatus with which to explain modern law. Austin's work and Maine's were reviewed together, and many reviewers regarded the works as complimentary. Many readers of Maine did not feel compelled to relate doctrinal changes to wider social developments; but they did draw the lesson that to understand the shape and purpose of modern legal doctrine, it was necessary to trace the history of the doctrine.

In taking this historical approach to doctrine, they were not influenced only by Maine's version, but also looked to the German historical school and in particular the example of Savigny. Although Savigny felt that law was at base the custom of the people - and manifested its spirit or Volksgeist - and that it developed organically over time, he argued that as society specialised, so that part of the Volksgeist was articulated through the voices of jurists, who had the task both of developing the law and of giving it systematic unity. ${ }^{33}$ For Savigny, the task of the legal historian was to uncover leading principles and notions, which could then be systematised - as Savigny himself did in his System des heutigen römischen Rechts. Savigny - and the Pandectist school which provided the very model for midnineteenth century reformers of legal education - united a historical and an analytical approach. As he put it, the essence of the systematic method was to set out the connections,

of Contracts (1867).

${ }^{31}$ See further Raymond Cocks, Sir Henry Maine: A Study in Victorian Jurisprudence (1988), and Michael Lobban, A History of the Philosophy of Law in the Common Law World (2007), 189-204.

${ }^{32}$ See e.g. Frederic Harrison, 'Maine on Ancient Law' (1861) 19 (n.s.) Westminster Review, 457-77 at 465.

${ }^{33}$ F.C. von Savigny, System des heutigen römischen Rechts, vol. 1 (1840), 45, §14. See also Mathias Reimann, 'Nineteenth Century German Legal Science', (1990) 31 Boston College LR 837 at 852-3. 
which wove together individual concepts and rules into a coherent whole. ${ }^{34}$

Later critics sometimes accused the 'formalists' of inhabiting that very 'heaven of legal concepts' which had been so mocked by Rudolf von Jhering. ${ }^{35}$ They also associated formalism with Austinian analytical jurisprudence, in which (in Pound's phrase) 'new situations were always to be met by deductions from traditional fixed conceptions' ${ }^{36}$ It is clear that this generation of jurists was very influenced by Austinian analytical toolbox of concepts; but they did not think that these conceptual tools could themselves determine the content of the law, or generate answers to new legal questions. Instead, they were to be used better to arrange the materials of historical case law.

The importance of analytical jurisprudence is perhaps best seen by its use by scholars who were sceptical about Austin. Frederick Pollock - who proclaimed that 'the philosophy of the English or "analytical" school is not mine",37 - nonetheless engaged with in the Austinian enterprise of seeking accurate definitions for the purposes of classification. In his First Book of Jurisprudence, he explained that [i]n order to have any real working acquaintance with a system of law we must inquire, not only what duties and rights are recognised, but how rights are acquired and lost; what rights are capable of transfer, and how; by what acts and events duties are imposed; how far and in what ways duties can be transmitted; and how they are discharged. ${ }^{38} \mathrm{He}$ explained that the classifications and divisions made by lawyers were 'formal' ways of 'reducing the world of human action to manageable items'. ${ }^{39}$ One such classification was the classical distinction between the duties and rights owed to particular individuals (in personam) - such as contractual duties - and those owed to the world at large (in rem).${ }^{40}$ Pollock's treatment was clearly influenced by Austin's discussion. Thus, he defended the method of distinguishing the 'general part' from the 'special part', since it was convenient for purposes of exposition that 'those principles and rules which are found in all or most portions of the subject ... are disposed of before the several branches are entered

\footnotetext{
${ }^{34}$ Savigny (n. 33) xxxvi.

${ }^{35}$ Rudolf von Jhering, 'In the Heaven of Legal Concepts: a Fantasy', trans. Charlotte L.
} Levy, (1985) 58 Temple LQ 799. See Felix S. Cohen, 'Transcendental Nonsense and the Functional Approach', (1935) 35 Columbia LR 809-49.

${ }^{36}$ Quoted in Sebok (n. 3) 45.

${ }^{37}$ Frederick Pollock, A First Book of Jurisprudence for Students of the Common Law (1896) vii.

${ }^{38}$ Ibid. 73.

${ }^{39}$ Ibid. 80.

${ }^{40}$ Ibid. 81. Pollock also noted the distinction between 'Substantive and Adjective law', ibid. 97. 
upon. ${ }^{41}$ Elsewhere, he argued that comparative study could disclose 'typical conceptions which are common to all legal systems' and that the jurist could deduce some necessary 'general ideas of law', including duty, intent, negligence, ownership and possession from a study of such systems. ${ }^{42}$

In his early publications, Holmes also sought to devise an analytical a system of classification, based on different kinds of duties. Taking a critical view of Austin's method, he argued that any arrangement of law had to be made on the basis of duties, not rights, since duties preceded rights both 'logically and chronologically' ${ }^{43}$ For Holmes, the purpose of classification was to make the law knowable: this was best done by proceeding 'from the most general conception to the most specific proposition or exception in the order of logical subordination'. ${ }^{44}$ In his first article setting out his system of classification on the basis of duties, Holmes criticised Austin's definition of law as the command of the sovereign, making the point that 'by whom a duty is imposed must be of less importance than the definiteness of its expression and the certainty of its being enforced'. ${ }^{45}$ If this seemed to prefigure some of Holmes's later suggestions that law was to be found in what courts actually did, the point he was making here was that international law - in which the rules were so definite that they could be digested in case books and where violations were in fact punished - was a proper subject for a law book, and was something to be included in a comprehensive classification. Consequently, his classification began with the duties of sovereign powers to each other, before turning to the duties owed to the sovereign by citizens, and the various categories of duties citizens might owe each other. These duties were tabulated in a series of articles which followed. Holmes was here attempting to improve upon Austin's method of classification, not to abandon its ambition.

Langdell himself had read Austin, and was clearly influenced by his method of analysis and classification. ${ }^{46}$ Although few of the systematic treatise writers of the late nineteenth century wrote extensively about the analytical method, they accepted the notion that a taxonomy of legal concepts could be made, which distinguished between the major categories of law, and which helped clarify the meaning of notions such as right and duty, which were to be found in all advanced legal systems. However, it did not follow that once the jurist had uncovered the structure of legal concepts, he would be able to deduce the content of the rules as a matter

${ }^{41}$ Ibid. 102.

${ }^{42}$ Frederick Pollock, 'The Methods of Jurisprudence', in Oxford Lectures and Other Discourses (1890), 10.

${ }^{43}$ Holmes, 'Codes' (1870) 5 American LR 1 at 3. See also O.W. Holmes, 'The Arrangement of the Law: Privity' (1872) 7 American LR 46.

${ }^{44}$ Holmes, 'Privity', (1872) 7 American LR 47n. Cf. O.W, Holmes, 'Possession' (1878) 12 American LR 688 at 702.

${ }^{45}$ Holmes, 'Codes', (1870) 5 American LR 1 at 4.

${ }^{46}$ See C.C. Langdell, 'A Brief Survey of Equity Jurisdiction' (1887) 1 Harvard LR 55-8 and 'Classification of Rights and Wrongs' (1900) 13 Harvard LR 537-56 and 659-78. 
of logic. ${ }^{47}$ The late nineteenth century jurists used the tools of Austinian analysis to classify and distinguish areas of doctrine found in the common law cases. They remained part of a common law tradition of juridical thought insofar as they did not - except in the most formal sense - see law in terms of the commands of a sovereign legislator and his subordinates, but as a body of principles and rules which developed with the community and was found in its case law. At the same time, they drew the lesson of Maine, that legal doctrines and even legal concepts were not timeless, but were often contingent, that their development had to be traced by a careful study of the sources, and that this might lead the jurist to re-evaluate the doctrine. This explains why so many of these jurists - including Langdell, Holmes, Ames and Bigelow - spent so much time exploring the history of legal doctrines, tracing the evolution of ideas from the medieval Year Books onwards. ${ }^{48}$

The centrality of historical, rather than purely logical, analysis to these scholars' explanation of doctrines can be seen particularly clearly in the late nineteenth century debates over the nature and function of consideration in contract. If Langdell's discussion of offer and acceptance seemed to have a tinge of scholastic logic about it (inviting Holmes's barb), his treatment of consideration - that quirk of common law contract doctrine, which held that an informal contract was only binding if there had been a benefit given to the promisor or a detriment suffered by the promisee - was rooted in historical argumentation. Langdell explained that there were two kinds of consideration, which were respectively enforced by the actions of debt (the more ancient form) and of assumpsit (which was of more recent growth). ${ }^{49}$ They were different in nature: the essence of consideration in debt cases was the benefit conferred on the debtor, while in assumpsit, it was the detriment suffered by the promisee. In a very compressed discussion, Langdell explained how the rise of the action of assumpsit had modified as well as relaxed the old consideration. It was not a necessary development, for it would have been perfectly rational for the courts to require no consideration in assumpsit cases; '[b]ut whatever may have been the merits of the question originally, it was long since conclusively settled. ${ }^{, 50}$ If Langdell's ultimate conclusion seemed dogmatically definitional - that detriment was the essential feature of consideration in assumpsit - it was a dogma derived from historical analysis. Holmes in turn expanded on the topic in The Common Law, where he argue that it was necessary to know something about the ancient action of debt 'to understand the enlightened rules which make up the law of contract at the present time. ${ }^{51} \mathrm{He}$ dug deeper than Langdell, giving a speculative history of the procedural origins of the requirement for a quid pro quo in cases of debt, and arguing that it

${ }^{47}$ Nor had this been Austin's argument: if the clarification of concepts would make it easier for the judge to understand the legal question which was being posed, he was still a subordinate legislator who was expected to decide novel cases on the basis of utility.

${ }^{48}$ On this, see Rabban (n. 6) 153-309.

${ }^{49}$ C.C. Landell, Summary of the Law of Contracts, $2^{\text {nd }}$ ed (1880), 58.

${ }^{50}$ Ibid. 61.

${ }^{51}$ O. W. Holmes, The Common Law (1881), 251. In Mainite vein, he added that 'whenever we trace a leading doctrine of substantive law far enough back, we are very likely to find some forgotten circumstance of procedure at its source' (253). 
was by a process of accident and analogy that a doctrine of consideration identified with detriment came to be applied in assumpsit. ${ }^{52}$ However, neither his conclusions nor his method were particularly out of line with Langdell's. Rather than being driven by the nature of the thing - as a matter of logical reasoning - both of these scholars saw the doctrine of consideration as being given shape by its history. At the same time, the need to account for the doctrine of consideration led both of these men to reject the - logical - will theory of contract, which had been favoured by European jurists such as Savigny, and instead to develop a 'bargain' theory. ${ }^{53}$ Moreover, this theory was the end-point of their explanation, rather than a starting point for further deductions.

A careful exploration of the history of legal doctrine could also raise questions about its nature and function, and its suitability for the modern age. Ames, who praised Langdell's focus on detriment as the key notion for consideration in developing his own history,${ }^{54}$ noted that the definition still left a crucial question unanswered: what was to be understood by 'detriment'? ${ }^{55}$ His historical examination of the topic revealed that courts had changed their approach over time: whereas an older stand of cases suggested that forbearance to prosecute an invalid claim was not regarded as a detriment, the more modern authorities took a different view, and one which 'accords well with the views of business men. ${ }^{56}$ A close study of the older cases also revealed that some modern views of consideration which disappointed the reasonable expectations of businessmen (such as the modern notion that part payment could not satisfy a larger debt) rested on misunderstandings of the historical material. Ames's conclusion from a study of the case law was that 'any act or forbearance given in exchange for a promise' - however minimal - could constitute the detriment required for consideration to be present. In his view, this meant that the mere act of uttering a promise could be consideration for a counter promise. ${ }^{57}$ Although Ames claimed that this made for 'logical

\footnotetext{
${ }^{52}$ Holmes (n. 51), 258, 285. Cf. O.W. Holmes, 'Early English Equity', (1885) 1 LQR 162 at 171.
}

${ }^{53}$ For Langdell, 'as every consideration is in theory equal to the promise in value, so it is in theory the promisor's sole inducement to make the promise' Langdell (n. 49) 78. For Holmes, 'the promise must be made and accepted as the conventional motive or inducement for furnishing the consideration': Holmes (n. 51) 293.

${ }^{54}$ Ames argued that the two aspects of consideration did not derived from the same root, but had different sources: the 'benefit' side derived from the action of debt, whereas the 'detriment' side derived from the action on the case for deceit, whence it migrated into the action of assumpsit for nonfeasance: J. B. Ames, 'The History of Assumpsit: I - Express Assumpsit', (1888) Harvard LR 1 at 14.

55 J.B.Ames, 'Two Theories of Consideration. 1. Unilateral Contracts' (1899) 12 Harvard LR 515 .

${ }^{56}$ Ibid. 518.

57 Ames, 'Two Theories of Consideration. II. Bilateral Contracts' (1899) 13 Harvard Law Review 29 at 32: 'the giving of the promise is not only an act, but an act that neither was under any obligation to give'. 
simplicity in the law' and was 'a just deduction from the decided cases' - it was also designed specifically to achieve a result which was desired by business. ${ }^{58}$ The debate over the nature of consideration continued to rage, and Ames's view remained a controversial one. ${ }^{59}$ What is significant for our purposes is that these scholars regarded the best interpretation of the doctrine which was to be found in the historical case law to be open to contestation and discussion, and were not loath to suggest interpretations which best fitted the needs of modern society.

In dealing with topics such as contract - what Maine had seen as the terminus ad quem of the development of western societies - the jurists at the end of the nineteenth century were discussing what they regarded as largely settled topics. Their aim was to interpret the case law and rules inherited from the past, rather than to point to ways in which the law should develop in the future. When Langdell discussed the rule to be adopted for contracts made by the post, it may have been a matter which (in his view) had not yet been settled definitely by the courts, but it was one for which he felt the rationale of the common law rules on offer and acceptance generated a clear answer. Policy considerations were, in this area, 'irrelevant' for the common lawyer, since the question could be settled by doctrinal reasoning (though as has been shown, Langdell also considered broader aspects of convenience in his discussion). ${ }^{60} \mathrm{In}$ dealing with topics such as contract law, these treatise writers sought to set down the 'general part', the general rules in the common law which determined how contracts were to be made, interpreted and dissolved. It was not part of their purpose to deal with particular different kinds of contracts, and the various policies which related to them: indeed, their very jurisprudential project was to get away from the fragmented works which had featured so prominently in the earlier literature. Nor were they concerned with the broader policy question of which contracts should be enforced, and which regulated, beyond (in some cases) the limited treatment offered in chapters on unlawful agreements. These were matters for legislation. In the law of contract, the 'formal' or 'general' part could be separated from the more 'substantive' questions or 'special' part which dealt with what kinds of contractual agreements should be maintained. ${ }^{61}$

\footnotetext{
58 Ames, 'Two Theories I' (1899) 12 Harvard LR 515 at 531.

${ }^{59}$ Holmes's view that a more significant act was required derived from his theoretical understanding of the function of consideration as 'the conventional inducement of the counter promise' - it was 'not a promise to pay damages or, etc, but an act imposing a liability to damages nisi.' He went on 'You commit a tort \& are liable. You commit a contract and are liable unless the event agreed upon, over which you may have no, and never have absolute, control, comes to pass'. M. DeWolfe Howe, The Holmes-Pollock Letters: the Correspondence of Mr Justice Holmes and Sir Frederick Pollock (1961), vol. I, 177.
}

${ }^{60}$ See Bruce A. Kimball, 'Langdell on Contracts and Legal Reasoning: Correcting the Holmesian Caricature', (2007) 25 Law and History Review 345 at 373-82.

${ }^{61}$ Although the 'classical' school is often associated with an ideology of freedom of contract, the doctrine set out in the general treatises was not incompatible with detailed regulatory regimes for particular kinds of contract: see, e.g. J.B. Matthews, The Law of Money Lending Past and Present (1906), Alan Leslie, The Law of Transport by Railway (1920). 
It was no coincidence that the most 'logical' common law treatises were to be found in the law of contract, for it was in this area of private law that jurists - whether Anglo-Saxon or continental - were most able to tease out rules in a largely abstract way. The law of torts, which was in flux in the later nineteenth century, presented a different kind of challenge to those who wanted to elucidate its principles: for if it was possible to define the elements of a contract without addressing the question of which kinds of contracts were to be enforced, it was much harder to define the elements of tort without considering which kinds of wrongs were to be redressed. When Holmes chided Langdell's striving for 'elegentia juris or logical integrity of the system as a system' in his review of the Summary, it was in part because of his awareness - at a time when he was developing his own ideas of tort - that the common law of torts could not be set out in this way. In the year before the review, in an article on tort, Holmes had already pointed to 'the failure of all theories which consider the law only from its formal side', since they failed to see that law was 'for ever adopting new principles from life at one end' while retaining 'old ones from history ... which have not yet been absorbed or sloughed off.' In this article, he argued that the 'secret root' of the law was the 'considerations of what is expedient form the community' which were 'traceable to public policy in the last analysis'. ${ }^{62}$ Nonetheless, if Holmes was sceptical about the purely logical method, it was his ambition at this time to look for the general principles in the common law governing liability in torts. Moreover, it was part of his own aim to develop 'a connected scheme to analyze the fundamental conceptions of the law' ${ }^{63}$ Although Holmes came to be seen as the first major critic of 'formalism', his own efforts to explain the law of torts stood at the centre of the project of explaining common law doctrines and coherent bodies of law based on identifiable principles, which stood at the heart of the project of the private law treatise writers at the end of the nineteenth century.

The principles governing tort could not be figured out as a matter of a priori definition, at least not unless the view was taken that all actors should be held strictly liable in tort for harms caused by their acts. However, this was not a theory which could explain the common law, which had seen a recent expansion of the doctrine of negligence. Nor, in Holmes's view, was it a theory which made logical sense, given the potentially infinite chain of causation for any event which resulted in harm. ${ }^{64}$ Rather than being purely logical, a theory of tort had to explain the developing doctrine of the common law in the best way. In common law style, Holmes sought to derive a theory which would both explain the principle behind the doctrine, and show how it served the needs of the present society. Part of this project entailed looking at the history of the common law to explain the ambit of certain doctrines, which might (as with the case of consideration) call into question present understandings which were based on a flawed reading of history. Holmes did this in his article of 1879 on 'Common Carriers',

${ }^{62}$ O.W. Holmes, 'Common Carriers and the Common Law', (1879) 13 American LR 609 at 631.

${ }^{63}$ O. W. Holmes, 'Trespass and Negligence' (1880) 14 American LR 1 at 1n.

${ }^{64}$ Ibid. 9-10. 
which ended with a statement of his famous 'paradox of form and substance'. ${ }^{65}$ Holmes's aim in the article was to show the incoherence of the modern rule that common carriers were held strictly liable for damage to goods carried by them. A detailed discussion of legal history showed how the ancient law of bailments, which had held all bailees strictly liable for the loss of bailed goods (for which they had a remedy over against the thief) had been remodelled in the early modern era (in part because of the rise of assumpsit) to make common carriers strictly liable for any damage done to them (even though they had no remedy over). It was a doctrinal development which 'made the carrier's burden heavier than it was in the time of the Year Books'. ${ }^{66}$ Holmes's history aimed to show that one could only understand 'to what extent the old common law of bailment still survives' by 'enumerating the decisions in which the old law is applied'; but he added that if this were done, the scholar would 'find it hard to bring them together under a general principle. ${ }^{67}$ The point of Holmes's article was to show that '[i]f there is a sound rule of public policy which ought to impose a special responsibility upon common carriers, as those words are now understood, it has never yet been stated'; for the policy which shaped the early modern developments had been 'part of a protective system which has passed away'. Without being placed on such firm foundations, the doctrine of strict liability was like the 'clavicle in the cat,' surviving after its use had been forgotten, and resulting in 'failure and confusion from the merely logical point of view. ${ }^{68}$ In Holmes's view, doctrine had to be tested by asking what function it fulfilled, and whether it fulfilled it in a coherent fashion.

Holmes went on to develop his own theory of torts, which sought to marginalise strict liability. In 'Trespass and Negligence', he argued that 'the principle of our law is that loss from accident must lie where it falls', even where the instrument of misfortune was another person, unless that person could have foreseen and avoided the harm. This argument was based in part on logic - or arguments from 'consistency', as Holmes put it. It also relied on an examination of historical authorities, for he claimed that the common law had 'never known' a rule of strict liability. ${ }^{69}$ Holmes also invoked 'policy' once again, though the policy in question - that it was no more just to make a man liable for unforeseen harms done to another than to require him to insure that person against being struck by lightning - might as well be described as a moral or philosophical argument. It was in this article that Holmes developed his idea that the standard of care imposed was an objective one, not a subjective one. This theory was based in part on Holmes's 'policy' arguments about how societies could best be made to function - and in part on his interpretation of past common law cases. It was a theory which explicitly linked the development of the rules of the common law - in determining which acts were to be held as blameworthy - with the values of the community

${ }^{65}$ Holmes, 'Common Carriers', (1879) 13 American LR 609 at 631.

${ }^{66}$ Ibid. 625-6.

${ }^{67}$ Ibid. 628.

${ }^{68}$ Ibid. 630.

${ }^{69}$ Holmes, 'Trespass and Negligence' (1880) 14 American LR 1 at 7 ('unless in that period of dry precedent which is so often to be found midway between a creative epoch and a period of solvent philosophical reaction.') 
as expressed by a jury. According to his theory, people were to be punished for falling short of the standard which was regarded as morally blameworthy by the community. The legal standard was set by the jury, and then formulated into rules of law by courts over time. As he put it, '[a] judge who has sat at nisi prius ought gradually to acquire a fund of experience which enables him to represent the common sense of the community in ordinary instances far better than an average jury'. ${ }^{70}$

When seeking the principles of the law of tort, it was much more necessary to develop a theory about the content of that law - which harms were to be compensated and how far than was the case with contract law, where the jurist could much more easily define what a contract was, without having to discuss which contracts should be enforced. To that degree, Holmes's disagreement with Langdell may have reflected the fact that their main preoccupations at this time were on different areas of law. At the same time, Holmes's own work on tort suggests that he thought it possible to work out a theory of torts which would be able to guide the judge and jurist in making sense of the inherited case law and in guiding its future development. Holmes's project was ambitious: having in 1870 wondered whether that 'Torts is not a proper subject for a law book' ${ }^{71}$ he set out to uncover an underlying theory which could explain the area. While he repeatedly spoke of the scholar needing to look for 'policy', it was the 'policy of the law' which he here had in mind, for it was the jurist who was to develop the law rather than 'the man of statistics or the master of economics'. ${ }^{72}$

Holmes's approach to developing his theory of tort was entirely consistent with the wider aims of the late nineteenth century treatise writers. Indeed, it proved a model for other writers seeking a generalised theory of tort. They included Frederick Pollock, who declared in 1887 that 'the purpose of this book is to show that there really is a Law of Torts, not merely a number of rules of law about various kinds of torts - that this is a true living branch of the Common Law, not a collection of heterogenous instances. ${ }^{73}$ There were "elements of coherence' to be found in the cases, which showed that 'the law of torts is a body of law capable of being expressed in a systematic form under appropriate general principles'. ${ }^{74}$ Pollock said he had tried in the book 'to turn to practical account the lessons of what I saw and heard' at Harvard Law School, and noted that it had been 'put into shape after, or concurrently with, free oral exposition and discussion of the leading cases. ${ }^{, 75}$ Like Holmes. Pollock sought to tease a general principle out of heterogeneous case law, teasing 'authentic general principles' from a mass of particular remedies, general propositions for which there was no direct authority, but which best explained the underlying law. In the event, it proved very difficult for tort scholars to devise a coherent theory to explain the law of tort, and point

\footnotetext{
${ }^{70}$ Ibid. 33.

${ }^{71}$ Book Review, (1871) 5 American LR 340.

${ }^{72}$ The phrase is from Holmes' 'Path', (1897) 10 Harvard LR 457 at 469.

${ }^{73}$ Frederick Pollock, The Law of Torts (1887), vi.

${ }^{74}$ Ibid. 5.

${ }^{75}$ Ibid. vi.
} 
to principles which could explain its trajectory of development. In the view of some scholars, Holmes himself had lost faith in the enterprise by the $1890 \mathrm{~s},{ }^{76}$ although Pollock did not. Throughout the twentieth century, tort scholars like Pollock and his followers struggled to develop a theory which accurately reflected the doctrine it purported to explain: but they remained committed to the 'formalist' project of seeking coherence in the case law.

\section{$\mathbf{V}$}

In one respect, the Realist critique was correct. The treatise writers of the Gilded Age did not see judges (or jurists) as subordinate legislators, who were to be educated in how best to decide cases to make it fit present policy needs. They rather saw the common law as a system of adjudication between litigants. They assumed that a careful historical investigation of the existing case law, informed by a developed toolbox of analytical concepts, would help clarify the law, and help judges to make more consistent decisions. As Gray explained, if it was the judge who made the law in each individual case, there was great value in the judge being guided by settled sources of law, since it would avoid the need for everything to be worked out de novo in any case. If matters were not regarded as settled by authority, he argued, 'an army of judges would not suffice to keep a society moving' ${ }^{77}$ For men like Gray, careful scholarship could contribute further, by explaining the rationale of common law rules in a way which would ensure that legislators did not throw the law into confusion - and generating high litigation costs - by enacting careless legislation. ${ }^{78}$

In common with many generations of jurists before them, the thinkers often misnamed 'legal formalists' assumed that the law applied by the common law courts was coherent, and could be classified into distinct, broad categories. However, they did not think these categories were closed, nor that they were timeless, or unchanging, or unrelated to social needs. They saw the common law as a developing body, which served the needs of its community; but they sought to make better sense of it, by using the latest tools offered by analytical and historical jurisprudence.

\footnotetext{
${ }^{76}$ Whether Holmes adhered to his earlier views by the late 1890s is a matter of debate: see Daniel R. Ernst, 'The Critical Tradition of Writing American Legal History', (1993) 102 Yale LJ 1019.

${ }^{77}$ Gray (n. 15) 252.

${ }^{78}$ Gray (n. 9) v, 439-44.
} 


\section{BIBLIOGRAPHY}

Neil Duxbury, Patterns of American Jurisprudence (1995).

Grant Gilmore, The Ages of American Law (1977),

Thomas C. Grey, 'Langdell's Orthodoxy,' (1983) 45 University of Pittsburgh LR 1 at 28-32.

Morton J. Horwitz, The Transformation of American Law, 1870-1960 (1992).

Duncan Kennedy, The Rise and Fall of Classical Legal Thought (2006; $1^{\text {st }}$ written 1975).

Bruce A. Kimball, The Inception of Modern Professional Education: C.C. Langdell, 18261906 (2009).

William P. LaPiana, Logic and Experience: the Origin of Modern American Legal Education (1994).

David Rabban, Law's History: American Legal Thought and the Transatlantic Turn to History (2013).

Anthony J. Sebok, Legal Positivism in American Jurisprudence (1998)

Stephen A. Siegel, 'Joel Bishop's Orthodoxy', (1995) 13 Law and History Review 215.

Robert Stevens, Law School: Legal Education in America from the 1850s to the 1980s (1983).

Brian Z. Tamanaha, Beyond the Formalist-Realist Divide: the Role of Politics in Judging (2010)

G. Edward White, Tort Law in America: an Intellectual History, expanded ed. (2003)

W.M. Wiecek, The Lost World of Classical Legal Thought: Law and Ideology in America, 1886-1937 (1998). 